\title{
PENGARUH KEPERCAYAAN, KEMUDAHAN, DAN RESIKO TERHADAP PENGGUNAAN E-BANKING (Survei pada Nasabah BRI Syariah di Kota Palu)
}

Andi Fauziah'1, Tenripada ${ }^{2}$

1 Jurusan Akuntansi, Fakultas Ekonom, Universitas Tadulako, Palu

2 Jurusan Akuntansi, Fakultas Ekonom, Universitas Tadulako, Palu, andi.fauziah54@gmail.com

ABSTRAK

Penelitian ini bertujuan untuk menguji dan menganalisa Pengaruh Kepercayaan, Kemudahan dan Risiko Terhadap Penggunaan E-banking baik secara simultan maupun parsial. Penelitian ini menggunakan metode survei. Sampel dalam penelitian ini yaitu nasabah BRI Syariah yang berjumlah 74 responden. Sampel tersebut diambil berdasarkan metode sampling purposive. Teknik analisis yang digunakan yaitu metode regresi linear berganda dengan bantuan alat analisis software SPSS versi 25.0. Hasil dari penelitian ini, secara parsial Kepercayaan dan Kemudahan berpengaruh positif signifikan, sedangkan Risiko berpengaruh negatif dan signifikan. Kepercayaan, Kemudahan dan Risiko secara serempak berpengaruh positif signifikan terhadap Penggunaan
INFORMASI

ARTIKEL

Katakunci:

Kepercayaan, Kemudahan, Risiko, Penggunaan Ebanking 


\section{PENDAHULUAN}

Perkembangan teknologi yang semakin marak dan terjadi sangat pesat saat ini telah menyebabkan munculnya suatu aplikasi-aplikasi bisnis yang berbasis internet perbankan disebut dengan electronic atau Electronic Banking (E-banking). E-banking adalah produk layanan perbankan yang memanfaatkan internet sebagai media untuk menyalurkan data keuangan dari bank kepada nasabah melalui handphone, smartphone maupun komputer, yang bisa digunakan nasabah kapanpun dan dimanapun selama 24 jam.

Dunia perbankan dewasa ini telah menyadari bahwa nasabah saat ini tidak hanya mempertimbangkan bank apa saja tempat mereka menabung atau berinvestasi, tidak hanya mempertimbangkan bunga atau keuntungan yang akan didapatkan dalam perbankan tersebut, akan tetapi nasabah juga membutuhkan kecanggihan dan kelengkapan fitur dari suatu produk perbankan, karena saat ini yang dicari oleh nasabah tidak hanya value (nilai) yang akan didapatkan dari apa yang ditawarkan oleh pihak bank tersebut, melainkan kualitas dan kemudahan-kemudahan yang dapat membantu dan memperlancar transaksi nasabah tersebut. ${ }^{1}$

Diantara banyak perbankan syariah yang sudah meluncurkan atau menerapkan E-banking, BRI Syariah

1Nurdin, dkk (2020). Pengaruh Pelayanan Mobile Banking Terhadap Kepuasan Nasabah (Studi Pada Mahasiswa Perbankan Syariah IAIN Palu) Jurnal Ilmu Perbankan dan Keuangan Syariah, 2(2), 87-104. hadir dengan memberikan solusi bertransaksi dengan cepat, aman dan mudah melalui layanan electronic banking BRIS. Adapun 3 layanan E-banking Bank Rakyat Indonesia (BRI) Syariah yaitu SMS banking, internet banking, dan mobile banking (RipalSeptiana, 2018). ${ }^{2}$ Jumlah pengguna E-banking BRI Syariah di Indonesia telah mengalami perkembangan yang dapat dikatakan meningkat. Ditahun 2018 mampu menjaring sebanyak 2,85 juta rekening dengan jumlah volume mencapai 28,86 juta sedangkan ditahun 2019 mengalami peningkatan sebesar $16,72 \%$ atau sebanyak 3,32 juta rekening dengan jumlah volume sebanyak 34,12 juta (BRI Syariah, 2019). Secara garis besar dengan menggunakan E-banking banyak sekali keuntungan yang dapat diperoleh oleh penggunanya seperti halnya menghemat tenaga dan waktu karena $E$ banking jelas dapat dilakukan di mana saja dan kapanpun sepanjang penggunanya mempunyai akses untuk menggunakan layanan dari E-banking, seperti mesin ATM yang berada didekat lokasi, handphone, atau pun jaringan internet.

Kasus Cyber Crime yang terjadi yaitu kasus pembobolan ATM BRI Syariah di kampus IAIN Kota Palu, yang berhasil membawa uang senilai Rp.172.250.000,-penyidik saat ini telah mengamankan barang-barang bukti dan masih mengembangkan kasus itu untuk mengungkapkan pelaku lainnya.

\footnotetext{
${ }^{2}$ Ripal Septiani, (2018). https://efinansial.com/e-banking-bankbrisyariah/. (diakses, padatanggal 23 Februari 2020 pukul 19:12 Wita).
} 
(SultengTerkini.com,2018). ${ }^{3} \quad$ Penelitian ini menghasilkan bahwa variabel persepsi kemudahan penggunaan, persepsi kebermanfaatan dan keamanan berpengaruh positif dan signifikan terhadap penggunaan E-banking. Sedangkan variabel persepsi risiko berpengaruh negatif dan signifikan terhadap penggunaan E-banking. ${ }^{4}$

\section{TINJAUAN PUSTAKA}

\subsection{Kepercayaan}

\section{a. Pengertian Kepercayaan}

Kepercayaan merupakan harapan dan keyakinan seseorang terhadap orang lain akan kejujuran, kebaikan dan kesetiaan". ${ }^{5}$ Sedangkan menurut istilah kepercayaan adalah "suatu sikap yang ditunjukkan oleh manusia saat ia merasa tahu dan menyimpulkan bahwa dirinya telah mencapai kebenaran". ${ }^{6}$ Karena kepercayaan adalah suatu sikap, maka kepercayaan seseorang itu tidak selalu

${ }^{3}$ SultengTerkini.com, (2018). https://www.sultengterkini.com/2018/10/ 31/viral-di-medsos-pembobol-atm-brisyariah-palu-diringkus dipinrang L.(diakses, pada tanggal 15 Juni 2020 pukul 23:22 Wita).

${ }^{4}$ Oktabriantaro, A.P, Sulindawati, N.G.E dan Dewi P.E.D.M, 2017. Pengaruh Persepsi Kebermanfaatan, Persepsi Kemudahan, Keamanan Dan Persepsi Resiko Terhadap Penggunaan E-Banking Pada Mahasiswa Jurusan Akuntansi Program S1 Fakultas Ekonomi Universitas Pendidikan GANESHA, e-Journal S1 Ak Universitas Pendidikan Ganesha

5Pusat Bahasa Departemen Pendidikan Nasional, Kamus Besar BahasaIndonesia,Jakarta, Balai Pustaka,2008.Hlm.542

'Ismawati, Budaya Dan Kepercayaan Jawa, Yogyakarta: Gama Media, 2002,hlm.15 benar dan bukanlah merupakan suatu jaminan kebenaran.

b. Faktor yang menghilangkan kepercayaan

Ada beberapa faktor yang dapat menghilangkan kepercayaan yang sering terjadi, diantaranya yaitu : ${ }^{7}$

1. Perasaan kecewa merupakan suatu perasaan yang ketika menginginkan suatu hal tetapi tidak dapat diwujudkan sesuai dengan harapan. Perasaan kecewa bisa saja datang secara tiba-tiba, kekecewaan tersebut akan berpengaruh pada pola pikir manusia sehingga akan mengahadapi rasa marah dan sedih.

2. Kehilangan harapan bisanya terjadi pada saat seseorang menginginkan suatu harapan yang besar terhadap orang lain dan perasaan tersebut dapat merusak bagi jiwa manusia karena hal yang diinginkan tidak dapat terwujud". 6 Kehilangan harapan sama halnya dengan putus asa, hal ini sangat berpengaruh.

3. Perasaan marah menyangkut seluruh perasaan di dalam diri, dimulai dari beberapa rasa kejanggalan yang ada dihati sehingga menimbulkan kemarahan yang meledak, cepat dan sengit.

4. Perasaan berdosa, menyesal atau kecewa adalah perasaan yang menyakiti diri. Karena selalu menyalahkan diri sendiri terhadap apa yang telah dilakukan.

Untuk itu Allah sangat melarang perbuatan khianat atas amanah karena akan menghilangkan kepercayaan pada diri seseorang. Orang yang berkhianat sebenarnya sadar dan mengetahui bahwa dirinya telah keluar dari

7Ismawati, Budaya Dan Kepercayaan Jawa, Yogyakarta: Gama Media, 2002,hlm.15

e-ISSN: 2686-6625 
kepercayaan yang diberikan atau diamanahkan sebelumnya. Disebutkan dalam Quran surat Al-anfal Ayat 27 yang berbunyi

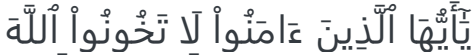

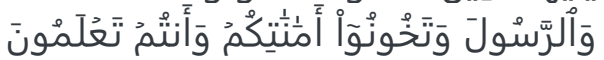

Terjemahan :

Wahai orang-orang yang beriman! Janganlah kamu mengkhianati Allah dan Rasul dan (juga) janganlah kamu mengkhianati amanat yang dipercayakan kepadamu, sedang kamu mengetahui.

Sikap amanah sangatlah terkait dengan masalah keimanan. Bahkan unsur kata dari keduanya amatlah dekat, iman - amanah - aman. Ketiga kata ini seakan memberikan sebuah pesan kepada kita bahwa sikap amanah adalah buah dari nilai keimanan yang melekat pada diri seseorang, dan apabila seseorang itu amanah atau menjaga kepercayaan yang diembakan atas dirinya maka amanlah ia. Hingga seseorang yang beriman tentulah perlu diuji dengan amanah atas apa yang dipercayakan pada dirinya. Jika hilang amanah maka berarti hilang pula keimanannya. ${ }^{8}$

\subsection{Kemudahan}

a. Pengertian Kemudahan

Kemudahan

Penggunaan, didefinisikan sebagai tingkat dimana seseorang meyakini bahwa penggunaan

${ }^{8}$ Abdul Jalil, Sitti Azizah Hamzah, "Pengaruh Bagi Hasil dan Kebutuhan Modal Terhadap Minat UMKM Mengajukan Pembiayaan Pada Lembaga Keuangan Syariah di Kota Palu", Jurnal Perbankan dan Keuangan Syariah Vol. 2 no. 2 (Tahun 2020), 190. https://jurnaljipsya.org/index.php/jipsya/artic le/view/31 (25 Mei 2021)
Teknologi informasi merupakan hal yang mudah dan tidak memerlukan usaha keras dari pemakainya. ${ }^{9}$

Kemudahan sesuai dengan firman allah dalam al-qur'an Q.S alinsyirah ayat 5-6:

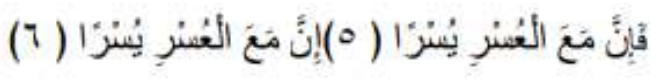

Terjemahan :

Maka Sesungguhnya bersama kesulitan ada kemudahan, Sesungguhnya bersama kesulitan ada kemudahan.

Dapat dijelaskan bahwa Allah SWT memberitahukan bahwa bersama kesulitan itu terdapat kemudahan. Kemudian Dia mempertegas berita tersebut. Ibnu Jarir meriwayatkan dari alHasaan, dia berkata: "Nabi SAW: Pernah keluar rumah pada suatu hari dalam keadaan senang dan gembira, dan beliau juga dalam keadaan tertawa seraya bersabda: "Satu kesulitan itu tidak akan pernah mengalahkan dua kemudahan, sesungguhnya bersama kesulitan itu terdapat kemudahan.

Kemudahan merupakan suatu keyakinan tentang proses pengambilan keputusan. Jika nasabah percaya dengan system informasi dan mudah untuk dipahami sehingga nasabah tetap akan memakainya. Sebaliknya jika dirasa sulit dipahami dan tidak percaya akan teknologi informasi yang ada maka nasabah tidak akan menggunakannya. Karakteristik kemudahan pengguna adalah mudah dipelajari, dipahami, simple dan mudah dalam pengoprasiannya

\subsection{Risiko}

a. Pengertian Risiko

Risiko merupakan keadaan (uncertainty) yang mempertimbangkan untuk memilih atau tidak menggunakan

${ }^{9}$ Davis, Perceived Usefulnes, Perceived Ease Of Use, And User Acceptance Of Information Tecnology. MS Quartertly (Online) Vol.13 Iss. 3, Pg 318.1989 
transaksi online. Ketidakpastian terhadap penggunaan sistem online menjadi pertimbangan bagi seseorang untuk menggunakan atau tidak menggunakan suatu transaksi secara online. Risiko yang terjadi pada E-banking biasanya berkaitan dengan keamanan pada system itu sendiri. 10

Semakin tinggi risikonya, maka pengguna tidak akan menggunakan $E$ banking. Ketika risiko yang dihadapi oleh nasabah semakin besar maka nasabah cenderung tidak berminat menggunakan $E$ banking. Sebaliknya ketika risikonya semakin kecil maka semakin besar pula kepercayaan nasabah untuk menggunakan E-banking dan Bank dapat menghemat biaya yang lebih besar untuk membuka kantor cabang.

\section{METHODOLOGY}

Jenis penelitian ini adalah kuantitatif dan kualitatif dengan menggunakan metode survei. Metode survey adalah metode dengan pengumpulan data primer yang diambil secara langsung dari sumber asli. Metode ini menggunakan pernyataan/pertanyaan tertulis yang memerlukan adanya kontak/hubungan antara subyek (responden) dengan peneliti agar mendapatkan data yang diinginkan. ${ }^{11}$

Populasi dalam penelitian adalah seluruh nasabah BRI Syariah pengguna $E$ banking di Kota Palu. Peneliti tidak dapat menentukan besarnya jumlah populasi yang ingin diteliti secara pasti dikarenakan tidak terdapat data yang relevan.

10 GilangRizky, Amijaya. Pengaruh Persepsi Teknologi Informasi, Kemudahan, Resiko Dan Fitur Layanan Terhadap Minat Ulang Nasabah Bank Dalam Menggunakan Internet Banking (Studi Pada Nasabah Bank BCA). Journal of Accounting. Universitas Diponegoro. 2010

11 Sugiyono. Metode Penelitian Kuantitatif, Kualitatif, dan R\&D. Bandung :n Alfabeta. 2017
Penelitian ini memakai teknik sampel sampling purposive yaitu teknik dengan penentuan sampel pertimbangan tertentu. Berdasarkan Rumus maka sampel penelitian ini yaitu 74 responden. ${ }^{12}$ Sampel penelitian ini yaitu nasabah pengguna $E$ banking BRI Syariah yang berlokasi di Kota Palu.

Teknik analisis data yang digunakan dalam penelitian ini adalah analisis kuantitatif. Yaitu proses analisis yang terdapat data-data yang berbentuk angka dengan cara perhitungan secara statistik untuk mengukur pengaruh pengetahuan terhadap minat berinvestasi di pasar modal syariah. Analisa data dilakukan melalui tahap uji validitas, reabilitas, uji regresi berganda, dan uji asumsi klasik. Untuk pembuktian hipotesis penulis menggunakan uji f dan uji t. ${ }^{13}$

\section{HASIL DAN PEMBAHASAN}

\subsection{Analisis Data}

Analisis data yaitu proses analisis yang terdapat data-data yang berbentuk angka dengan cara perhitungan secara statistik untuk mengukur pengaruh kepercayaan, kemudahan dan risiko terhadap penggunaan E-Banking (studi pada nasabah BRI Syariah di Kota Palu).

12 Carmen R. Wilson Van, Voorhis dan Betsy L. Morgan.. Understanding Power and Rules of Thumb for Determining Sample Sizes. Tutorials in Quantitative Methods for Psychology, 3.2007

13 Abdul Jalil . Pengaruh Beban Kerja, Stres Kerja dan Lingkungan Kerja Terhadap Kinerja Guru Madrasah Aliyah Negeri 2 Kota Palu.Jurnal Ilmu Perbankan dan Keuangan Syariah, 1(2), 117-134. 2019 


\section{a. Uji Intrumen Penelitian}

1) Hasil Uji Statistik

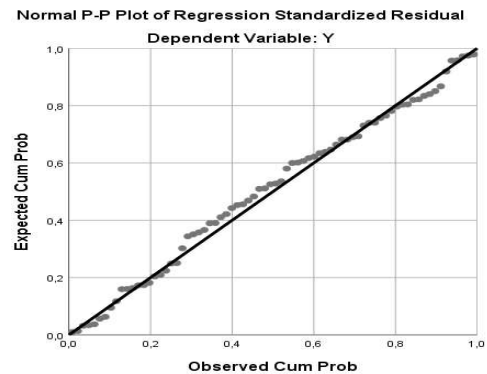

Gambar : Hasil Uji Normalitas

Berdasarkan hasil uji normalitas dan grafik normal plot, maka dapat ditarik kesimpulan bahwa grafik histogram pada normal plot dapat terlihat titik-titik menyebar disekitaran garis diagonal, penyebarannya mendekati dari garis diagonal. Grafik ini menunjukkan bahwa suatu model regresi dapat memenuhi asumsi normalitas.

\begin{tabular}{|r|r|}
\hline \multicolumn{2}{|c|}{ Collinearity Statistics } \\
\hline Tolerance & \multicolumn{1}{|c|}{ VIF } \\
\hline, 846 & 1,181 \\
\hline, 867 & 1,153 \\
\hline, 907 & 1,103 \\
\hline
\end{tabular}

Hasil Uji Multikolinearitas

Berdasarkan Tabel hasil uji multikolinearitas di atas, dapat dijelaskan hasil perhitungan dari nilai Tolerance lebih dari 0,10 dan nilai (VIF) menunjukkan kurang dari 10. Hal ini berarti bahwa tidak terjadi multikolinearitas antar variabel independen dalam model regresi.

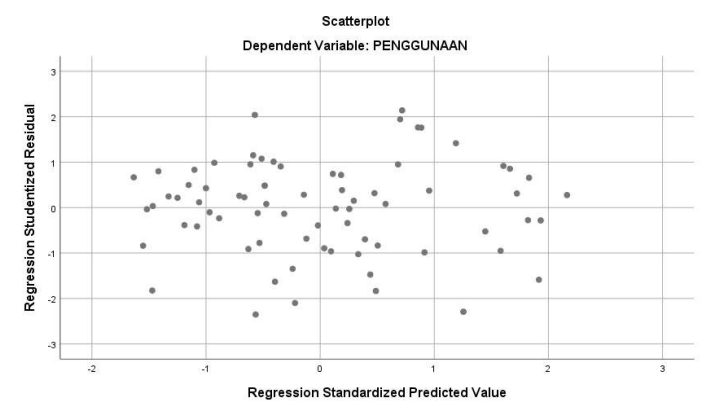

Berdasarkan gambar hasil Uji heterokedastisitas di atas, dapat dilihat bahwa titik-titik tersebut menyebar secara acak, serta tersebar dengan baik yang di atas ataupun yang di bawah angka 0 pada sumbu Y. Maka dapat disimpulkan bahwa tidak terjadinya heteroskedastisitas pada model regresi tersebut, sehingga untuk model regresi ini layak untuk digunakan.

\begin{tabular}{|c|c|c|}
\hline \multicolumn{3}{|c|}{ One-Sample Kolmogorov-Smirnov Test } \\
\hline & & $\begin{array}{c}\text { Unstandardiz } \\
\text { ed Residual }\end{array}$ \\
\hline \multicolumn{2}{|l|}{$N$} & 74 \\
\hline \multirow[t]{2}{*}{ Normal Parameters ${ }^{a, b}$} & Mean &, 0000000 \\
\hline & $\begin{array}{l}\text { Std. } \\
\text { Deviation }\end{array}$ & 2,66461087 \\
\hline \multirow{3}{*}{$\begin{array}{l}\text { Most Extreme } \\
\text { Differences }\end{array}$} & Absolute & ,068 \\
\hline & Positive &, 047 \\
\hline & Negative &,- 068 \\
\hline \multicolumn{2}{|l|}{ Test Statistic } & ,068 \\
\hline \multicolumn{2}{|c|}{ Asymp. Sig. (2-tailed) } & $200^{\mathrm{c}, \mathrm{d}}$ \\
\hline \multicolumn{3}{|c|}{ a. Test distribution is Normal. } \\
\hline
\end{tabular}

Berdasarkan tabel yang ada diatas menunjukkan bahwa hasil uji normalitas dengan uji Kolmogorov-Smirnov diperoleh nilai asymp. Sig. (2-tailed) sebesar 0,200 atau lebih dari 0,05 yang berarti residual terdistribusi secara normal

\begin{tabular}{|c|c|c|c|c|c|}
\hline No & $\begin{array}{c}\text { Variabel } \\
\text { Independen }\end{array}$ & $\begin{array}{c}\text { Koefisien } \\
\text { Regresi }\end{array}$ & t-hitung & Sig & $\begin{array}{c}\mathrm{r}- \\
\text { parsial }\end{array}$ \\
\hline 1 & Kepercayaan & 0,338 & 3,267 & 0,002 & 0,364 \\
\hline 2 & Kemudahan & 0,397 & 5,490 & 0,000 & 0,549 \\
\hline 3 & Risiko & $-0,249$ & $-3,411$ & 0,001 & $-0,378$ \\
\hline Konstanta $=7,293$ & Fhitung = 30,229 & Sig. F $=0,000$ \\
\hline $\mathrm{R}=0,751$ & $\begin{array}{l}\text { R.Square }=0,564 \\
\text { Adjusted R Square }= \\
\text { 0,546 }\end{array}$ & $\mathrm{a}$ & $=0,05$ \\
\hline
\end{tabular}

Berdasarkan nilai-nilai dari regresi yang telah diperoleh dari hasil analisis regresi linier berganda di atas, maka persamaan model regresi yang menggambarkan pengaruh kepercayaan, kemudahan, dan risiko terhadap penggunaan E-banking adalah sebagai berikut:

$$
\mathrm{Y}=7,293+0,338 \mathrm{X}_{1}+0,397 \mathrm{X}_{2}-0,249 \mathrm{X}_{3}+\varepsilon
$$


2) Hasil Uji Hipotesis

a. Hasil Uji F

\begin{tabular}{|c|c|c|c|c|c|c|}
\hline \multicolumn{7}{|c|}{ ANOVA $^{\mathbf{a}}$} \\
\hline & Model & $\begin{array}{l}\text { Sum of } \\
\text { Squares }\end{array}$ & df & $\begin{array}{l}\text { Mean } \\
\text { Square }\end{array}$ & $\mathrm{F}$ & Sig. \\
\hline \multirow{3}{*}{1} & Regression & 671,477 & 3 & 223,826 & 30,229 &, $000^{\mathrm{b}}$ \\
\hline & Residual & 518,311 & 70 & 7,404 & & \\
\hline & Total & 1189,788 & 73 & & & \\
\hline
\end{tabular}

b. Predictors: (Constant), RISIKO, KEMUDAHAN, KEPERCAYAAN

Berdasarkan hasil uji ANOVA (Analysis of Varian) atau $\mathrm{F}$ test diperoleh nilai $F_{\text {hitung }}$ sebesar $30,229>F_{\text {tabel }}$ sebesar 2,73 dan tingkat signifikansi lebih kecil dari taraf ketidakpercayaan $(0,000<0,05)$. Berdasarkan hasil tersebut, maka dapat diartikan bahwa secara simultan kepercayaan, kemudahan dan risiko berpengaruh positif signifikan terhadap penggunaan E-banking. Sehingga hipotesis pertama yang menyatakan bahwa kepercayaan, kemudahan dan risiko berpengaruh positif dan signifikan terhadap penggunaan E-banking.

\section{b. Hasil Uji t}

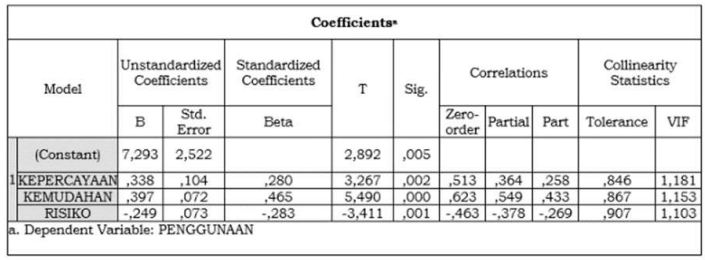

Berdasarkan hasil uji t diatas maka dapat diperoleh dengan hasil pengujian sebagai berikut:

1. Hasil uji regresi kepercayaan $\left(\mathrm{X}_{1}\right)$ diperoleh nilai $t_{\text {hitung }}$ sebesar $3,267>t_{\text {tabel }}$ sebesar 1,665 dan tingkat signifikansinya lebih kecil dari taraf kepercayaan $5 \%$ yaitu $0,002<0,05$. Dengan demikian, secara parsial variabel kepercayaan $\left(\mathrm{X}_{1}\right)$ berpengaruh positif signifikan terhadap penggunaan E-banking $(\mathrm{Y})$, artinya semakin tinggi kepercayaan maka akan semakin tinggi juga penggunaan $E$-banking BRI Syariah di Kota Palu. Berdasarkan hasil ini, maka hipotesis kedua dari penelitian ini, dimana kepercayaan berpengaruh positif signifikan terhadap penggunaan E-banking dapat diterima.

2. Hasil uji regresi kemudahan $\left(\mathrm{X}_{2}\right)$ diperoleh nilai $t_{\text {hitung }}$ sebesar $5,490>t_{\text {tabel }}$ sebesar 1,665 dan tingkat signifikansinya lebih kecil dari taraf kepercayaan $5 \%$ yaitu $0,000<0,05$. Dengan demikian, variabel kemudahan secara parsial $\left(\mathrm{X}_{2}\right)$ berpengaruh secara positif signifikan terhadap penggunaan E-banking BRI Syariah di Kota Palu (Y). Berdasarkan hasil ini, maka hipotesis ketiga dari penelitian ini, dimana kemudahan berpengaruh positif signifikan terhadap penggunaan $E$ banking dapat diterima.

3. Hasil uji regresi risiko $\left(\mathrm{X}_{3}\right)$ diperoleh nilai $t_{\text {hitung }}$ sebesar $-3,411>t_{\text {tabel }}$ sebesar 1,665 dan tingkat signifikansinya lebih kecil dari taraf kepercayaan 5\% yaitu $0,001<0,05$. Dengan demikian, variabel risiko secara parsial $\left(\mathrm{X}_{3}\right)$ berpengaruh secara negatif signifikan terhadap penggunaan E-banking BRI Syariah di Kota Palu (Y). Berdasarkan hasil ini, maka hipotesis keempat dari penelitian ini, dimana risiko berpengaruh negatif signifikan terhadap penggunaan E-banking dapat diterima.

\section{3) Pembahasan Hasil Penelitian}

Kepercayaan, Kemudahan dan Risiko secara simultan berpengaruh signifikan terhadap penggunaan E-banking BRI Syariah di Kota Palu. Hal ini memiliki arti bahwa penggunaan E-banking akan meningkat, seiring dengan meningkatnya kepercayaan, kemudahan dan risiko.

Kepercayaan secara parsial berpengaruh positif signifikan terhadap penggunaan E-banking BRI Syariah di Kota Palu. Hal ini memiliki arti bahwa layanan $E$ banking Syariah memiliki komponen fungsi salah satunya kerahasiaan data nasabah, sehingga nasabah tetap menggunakannya untuk keperluan perbankan.

Kemudahan secara parsial berpengaruh positif signifikan terhadap penggunaan E-banking BRI Syariah di Kota Palu. Hal ini menunjukkan bahwa nasabah merasa mudah saat mengaplikasikan $E$ banking tersebut, sehingga nasabah tetap tetap menggunakannya untuk keperluan perbankan.

Risiko secara parsial berpengaruh negatif signifikan terhadap penggunaan $E$ banking BRI Syariah di Kota Palu. Hal ini menunjukkan bahwa rendahnya risiko yang terjadi dalam penggunaan layanan $E$ banking yang ditawarkan oleh pihak BRI Syariah, sehingga nasabah tetap 
menggunakannya untuk keperluan perbankan.

\section{Kesimpulan}

Berdasarkan hasil penelitian, dapat disimpulkan bahwa :

a. Kepercayaan, Kemudahan dan Risiko secara simultan berpengaruh signifikan terhadap penggunaan E-banking BRI Syariah di Kota Palu.

b. Kepercayaan secara parsial berpengaruh positif signifikan terhadap penggunaan E-banking BRI Syariah di Kota Palu

c. Kemudahan secara parsial berpengaruh positif signifikan terhadap penggunaan E-banking BRI Syariah di Kota Palu.

d. Risiko secara parsial berpengaruh negatif signifikan terhadap penggunaan E-banking BRI Syariah di Kota Palu

\section{DAFTAR PUSTAKA}

Amijaya, GilangRizky. 2010. Pengaruh Persepsi Teknologi Informasi, Kemudahan, Resiko Dan Fitur Layanan Terhadap Minat Ulang Nasabah Bank Dalam Menggunakan Internet Banking (Studi Pada Nasabah Bank BCA). Journal of Accounting. Universitas Diponegoro.

Davis, Perceived Usefulnes, Perceived Ease Of Use, And User Acceptance Of Information Tecnology. MS Quartertly (Online) Vol.13 Iss. 3, Pg 318.1989

Ismawati, Budaya Dan Kepercayaan Jawa, Yogyakarta: Gama Media, 2002,hlm.15

Jalil, A. (2019). Pengaruh Beban Kerja, Stres Kerja dan Lingkungan Kerja Terhadap Kinerja Guru Madrasah Aliyah Negeri 2 Kota Palu. Jurnal Ilmu Perbankan dan Keuangan Syariah, 1(2), 117-134.
Jalil, A., \& Hamzah, S. A. (2020). PENGARUH BAGI HASIL DAN KEBUTUHAN MODAL TERHADAP MINAT UMKM MENGAJUKAN PEMBIAYAAN PADA LEMBAGA KEUANGAN SYARIAH DI KOTA PALU. Jurnal Ilmu Perbankan dan Keuangan Syariah, 2(2), 178-198.

Nurdin, N., Musyawarah, I., Nurfitriani, N., \& Jalil, A. (2020). Pengaruh Pelayanan Mobile Banking Terhadap Kepuasan Nasabah (Studi Pada Mahasiswa Perbankan Syariah IAIN Palu) Jurnal Ilmu Perbankan dan Keuangan Syariah, 2(2), 87-104.

Sugiyono. 2017. Metode Penelitian Kuantitatif, Kualitatif, dan $R \& D$. Bandung : Alfabeta.

Septiana, Ripal. (2018). https://efinansial.com/e-bankingbank-brisyariah/. (diakses, padatanggal 23 Februari 2020 pukul 19:12 Wita).

SultengTerkini.com, (2018).https://www.sultengterkini.c om/2018/10/31/viral-di-medsospembobol-atm-bri-syariah-paludiringkus-di-pinrang/.(diakses, pada tanggal 15 Juni 2020 pukul 23:22 Wita).

Oktabriantaro, A.P, Sulindawati, N.G.E dan Dewi P.E.D.M, 2017. Pengaruh Persepsi Kebermanfaatan, Persepsi Kemudahan, Keamanan Dan Persepsi Resiko Terhadap Penggunaan E-Banking Pada Mahasiswa Jurusan Akuntansi Program S1 Fakultas Ekonomi Universitas Pendidikan GANESHA, e-Journal S1 Ak Universitas Pendidikan Ganesha.

Pusat Bahasa Departemen Pendidikan Nasional, Kamus Besar BahasaIndonesia,Jakarta, Balai Pustaka,2008.Hlm.542

Voorhis, Carmen R. Wilson Van dan Betsy L. Morgan. 2007. Understanding Power and Rules of Thumb for Determining Sample Sizes. Tutorials in Quantitative Methods for Psychology, 3. 